\title{
Hubungan Kadar 25-Hidroksi-Vitamin D dengan HbA1c Melalui Interleukin-17 pada Anak Diabetes Melitus Tipe 1
}

Wahyu Wibisono, Harjoedi Adji Tjahjono, Edy Wijayanto

Bagian Ilmu Kesehatan Anak Fakultas Kedokteran Universitas Brawijaya/RSUD Dr Saiful Anwar, Malang

Latar belakang. Diabetes melitus tipe 1 (DMT1) merupakan penyakit autoimun yang ditandai oleh destruksi sel $\beta$ pankreas dan berhubungan dengan aktivitas Th17.

Tujuan. Mengetahui hubungan antara kadar vitamin D dengan kadar HbA1c melalui IL-17 pada anak dengan DMT1.

Metode. Desain cross-sectional dan melibatkan 20 subjek DM dan 20 kontrol sehat. Kadar vitamin D diukur dengan metode EIA (ng/ $\mathrm{mL}$ ), kadar HbA1c diukur dengan metode kromatografi menggunakan HPLC (\%), IL-17 diukur dengan metode ELISA (pg/mL). Hasil. Kadar vitamin D pada kelompok DMT1 lebih rendah dibandingkan kelompok kontrol ( $<<0,05)$. Kadar HbA1c dan IL-17 pada kelompok DMT1 lebih tinggi dibandingkan kelompok kontrol ( $\mathrm{p}<0,05)$. Uji korelasi pada kelompok DMT1 menunjukkan bahwa kadar vitamin D berkorelasi positif dengan kadar IL-17 $\left(\mathrm{p}<0,05, \mathrm{R}^{2}=0,566\right)$, sedangkan kadar IL-17 berkorelasi negatif dengan kadar HbA1c $\left(\mathrm{p}<0,05, \mathrm{R}^{2}=0,489\right)$. Namun demikian, analisis jalur menunjukkan bahwa vitamin $\mathrm{D}$ berhubungan tidak signifikan dengan HbA1c melalui IL-17 ( $\left.>>0,05, \mathrm{R}^{2}=-0,267\right)$.

Kesimpulan. Vitamin D lebih rendah pada kelompok DMT1, tetapi kadar HbA1c dan IL-17 lebih tinggi pada kelompok DMT1. Pada kelompok DMT1, vitamin D berhubungan dengan HbA1c melalui IL-17, tetapi tidak signifikan. Sari Pediatri 2016; $17(6): 469-77$.

Kata kunci: diabetes melitus tipe 1, HbA1c, IL-17, vitamin D

\section{Association of 25-Hydroxy-Vitamin D Level with HbAlc through Interleukin-17 in Children with Type 1 Diabetes Mellitus}

Wahyu Wibisono, Harjoedi Adji Tjahjono, Edy Wijayanto

Background. Type 1 Diabetes Mellitus (T1DM) is an autoimmune disease which characterized by pancreatic $\beta$ cells destruction and associated with Th17 activity.

Objective. To investigate association of vitamin D level with HbA1c level through IL-17 in children with T1DM.

Method. This study was designed as a cross-sectional study and involving 20 subjects with DM and 20 healthy subjects as control. Vitamin D level was measured by EIA method $(\mathrm{ng} / \mathrm{mL})$, while HbA1c level was measured by chromatography method using HPLC (\%), and IL-17 was measured by ELISA method (pg/mL).

Result. Vitamin D level in T1DM was significantly lower as compared to control group ( $<<0.05$ ). HbA1c and IL-17 level was significantly higher in T1DM as compared to control group $(\mathrm{p}<0.05)$. Correlation study in T1DM group showed that vitamin D level was positively correlated with IL-17 level $\left(\mathrm{p}<0.05, \mathrm{R}^{2}=0.566\right)$, whereas IL-17 level was negatively correlated with HbA1c level $\left(\mathrm{p}<0.05, \mathrm{R}^{2}=0.489\right)$. However, path analysis showed that vitamin D insignificantly correlated with HbA1c through IL-17 ( $>0.05$, $\left.\mathrm{R}^{2}=-0.267\right)$.

Conclusion. We concluded that vitamin D level was lower in T1DM group, but HbA1c level and IL-17 level were higher in T1DM group. In T1DM group, vitamin D insignificantly correlated with HbA1c through IL-17. Sari Pediatri 2016; 17(6):469-77.

Keywords: HbA1c, IL-17, type 1 diabetes mellitus, vitamin D

\footnotetext{
Alamat korespondensi: Dr. Wahyu Wibisono, Dr. Harjoedi Adji Tjahjono, Sp.A(K). Bagian IKA FK-UNIBRAW/RS Dr. Syaiful Anwar. Jl. Kol Sutarto 161, Malang, JATIM. Tel.+62341369393. E-mail: haryudi_aji2000@idai.or.id, haryudi_aji2000@yahoo.com
} 
$\mathrm{D}$ iabetes melitus tipe 1 (DMT1) 90\% terjadi pada anak dan remaja. Insidennya bervariasi di seluruh dunia, tertinggi di Finlandia yaitu 40/100.000 populasi dan terendah di Cina 0,1/100.000 populasi. ${ }^{1}$ Data Unit Kerja Koordinasi (UKK) Endokrinologi Anak Pengurus Pusat Ikatan Dokter Anak Indonesia (PP IDAI), jumlah pasien DM tipe 1 sebesar 731 pasien pada tahun 2012. ${ }^{2}$ Di Rumah Sakit Saiful Anwar (RSSA) Malang antara tahun 2005-2013 terdapat 35 pasien DMT1 berusia 1-18 tahun. ${ }^{3}$

Diabetes melitus tipe 1 adalah penyakit autoimun kronis yang disebabkan oleh kerusakan lebih dari 70\%-90\% sel $\beta$ pankreas sehingga terjadi kegagalan produksi insulin. ${ }^{4,5}$ Proses autoimun pada DMT1 telah dilaporkan berkaitan dengan proliferasi dan aktivasi sel T helper 17 (Th17). ${ }^{6}$ Mekanisme yang mendasari proliferasi dan aktivasi sel Th17 masih belum diketahui dengan jelas, ${ }^{7}$ tetapi beberapa penelitian telah melaporkan bahwa aktivasi Th17 berkaitan dengan asupan nutrisi seperti natrium ${ }^{8}$ dan vitamin D. ${ }^{9,10}$

Pemberian vitamin D (kalsitriol) bentuk aktif dilaporkan dapat menghambat pertumbuhan sel Th17 melalui hambatannya pada sinyal Nuclear factor $-\kappa B$ (NF-кB). ${ }^{9,10}$ Interleukin 17 (IL-17) diekspresikan oleh sel Th 17 dan telah diiteliti perannya sebagai mediator pro-inflamasi pada berbagai penyakit autoimun khususnya DMT1. ${ }^{1-13}$ Penelitian ini bertujuan untuk mengetahui hubungan antara kadar vitamin $\mathrm{D}$ dengan kadar HbA1c (kontrol glikemik) melalui IL-17 pada anak dengan DMT1.

\section{Metode}

Desain penelitian cross-sectional (analitik observasional) untuk membandingkan kadar vitamin D, IL-17, dan HbA1c pada anak dengan DMT1. Penelitian ini telah disetujui oleh Komite Etik Penelitian Rumah Sakit Saiful Anwar, Malang.

Dilibatkan 40 subjek, terbagi sama banyak menjadi 2 kelompok (kelompok DMT1 dan kontrol). Kriteria inklusi meliputi didiagnosis sebagai DMT1 dengan Glutamic Acid Decarboxylase $\left(\mathrm{GAD}_{65}\right)$ positif, usia antara 1-18 tahun, diijinkan oleh orang tua (informed consent). Kriteria eksklusi untuk subjek DM adalah pasien DMT1 dengan infeksi lokal atau sistemik, gangguan hepar dan ginjal, anemia, konsumsi vitamin
D dalam 3 minggu sebelum penelitian. Kriteria inklusi subjek kontrol adalah usia 1-18 tahun, $\mathrm{GAD}_{65}$ negatif, dan diizinkan oleh orang tuanya (informed consent). Kriteria eksklusi untuk kontrol adalah $\mathrm{GAD}_{65}$ positif, infeksi lokal atau sistemik, gangguan hepar atau ginjal, anemia, konsumsi vitamin $\mathrm{D}$ dalam 3 minggu sebelum penelitian. Semua subjek (kontrol dan DM) diambil dari Poli Rawat Jalan Anak Rumah Sakit Saiful Anwar, Malang.

Kadar vitamin D $(25(\mathrm{OH}) \mathrm{D})$ total diperiksa dengan metode ELISA pada serum darah melalui prinsip competitive-binding sesuai dengan petunjuk yang tertera pada kit. Sampel yang sudah ditambahkan EDTA atau heparin dimasukkan dalam tabung polipropilen dan disimpan pada suhu $-200^{\circ} \mathrm{C}$. Masing-masing tabung dikelompokkan menjadi kontrol, sampel, dan kalibrator. Biotin solution $1 \mathrm{~mL}$ 25-D ditambahkan pada semua tabung, kemudian disentrifugasi selama 10 detik. Dari masing-masing tabung dipindahkan $200 \mu \mathrm{L}$ ke sumur pada antibody coated-microplate, tutup dengan plastik, inkubasi pada suhu $18-25^{\circ} \mathrm{C}$ selama 2 jam. Setelah inkubasi, setiap sumur dicuci 3 kali dengan wash solution. Ditambahkan $200 \mu$ enzim konjugat pada masing-masing sumur, kemudian ditutup dengan plastik. Proses berikutnya adalah inkubasi pada suhu $18-25^{\circ} \mathrm{C}$ selama 30 menit. Tetra Methyl Benzidine (TMB) $200 \mu \mathrm{L}$ ditambahkan pada semua sumur, ditutup dengan plastik, dan inkubasi kembal pada suhu $18-25^{\circ} \mathrm{C}$ selama 30 menit. Setelah penambahan $100 \mu \mathrm{l}$ stop solution, 30 menit kemudian spesimen siap untuk dianalisis absorbansinya menggunakan microplate reader.

Kadar IL-17 diukur dengan metode ELISA sesuai dengan petunjuk kit. Sampel darah yang telah disentrifugasi, supernatan diencerkan dengan assay buffer (1:10), kemudian dimasukkan ke dalam microplate dan diinkubasi pada suhu $4^{\circ} \mathrm{C}$ semalam. Suspensi sampel dicuci dengan PBS-Tween 3 kali masing-masing selama 5 menit, kemudian ditambahkan $50 \mu \mathrm{L}$ blocking buffer [bovine serum albumin (BSA) 1\% dalam phosphate buffer saline (PBS)] selama 45 menit. Selanjutnya dilakukan pencucian reagen dengan PBS-Tween 3 kali masing-masing selama 5 menit. Sampel kemudian diinkubasi dengan $100 \mathrm{uL}$ antibodi primer dalam larutan PBS-BSA $1 \%$ dengan (1:500) selama 2 jam. Suspensi diambil dan dicuci kembali dengan PBS-Tween 3 kali masing-masing selama 5 menit. Selanjutnya diinkubasi dengan antibodi sekunder dalam buffer saline (1:2500) 
selama 90 menit. Suspensi diambil dan dicuci dengan PBS-Tween 2 kali masing-masing selama 5 menit. Selanjutnya dilakukan penambahan $50 \mu \mathrm{L}$ substrat para-Nitrophenylphosphate (pNPP) dan diinkubasi selama 30 menit. Reaktan dicuci dengan PBS-Tween 2 kali masing-masing selama 5 menit. Kemudian substrat TMB dimasukkan dan diinkubasi selama 30 menit. Reaksi dihentikan dengan menambahkan natrium hidroksida $(\mathrm{NaOH}) 1 \mathrm{~N}$ selama 15 menit. Hasil dibaca pada ELISA reader dengan panjang gelombang $450 \mathrm{~nm}$, kemudian absorbansi yang diperoleh dikonversi dengan persamaan dalam kurva standar sehingga diperoleh kadar dari IL-17 dalam satuan $\mathrm{pg} / \mathrm{mL}$.

Pemeriksaan HbA1c dilakukan dengan high performance liquid chromatography (HPLC). Sampel darah utuh (whole blood) $1 \mathrm{~mL}$ dimasukkan dalam tabung yang mengandung EDTA, $5 \mu \mathrm{L}$ sampel dicampur dengan 1,5 ml cairan buffer sebelum dianalisis, kemudian diperiksa dengan alat Bio-Rad D-10TM.

Analisis data meliputi uji normalitas (KolmogorovSmirnov), uji beda kadar vitamin D, IL-17, dan HbA1c di antara kelompok (independent t-test), uji hubungan dengan analisis jalur (path analysis), dan analisis koefisien determinasi (KD). Uji statistik dilakukan dengan bantuan software SPSS versi 17.0 for Windows.

\section{Hasil}

Tabel 1 menunjukkan karakteristik subjek penelitian pada kelompok DMT1 dan kelompok kontrol berdasarkan rerata usia, distribusi usia, jenis kelamin, rerata lama DM, status gizi, dan frekuensi pemantauan gula darah mandiri. Karakteristik subjek berdasarkan gambaran hasil laboratorium (darah lengkap, tes fungsi ginjal dan hepar, HbAlc, vitamin D, dan IL-17) tertera pada Tabel 2.

Gambar 1 menunjukkan bahwa kadar vitamin D secara bermakna lebih rendah pada kelompok DMT1 $(20,1 \pm 5,9) \mathrm{ng} / \mathrm{mL}$ dibandingkan kelompok kontrol $(33,9 \pm 3,6) \mathrm{ng} / \mathrm{mL}$ (independent $t$-test, $\mathrm{p}<0,05)$. Kadar HbA1c secara bermakna lebih tinggi pada kelompok DMT1 $(9,78 \pm 1,68) \%$ dibandingkan kelompok kontrol $(5,00 \pm 0,21) \%$ (independent $t$-test, $\mathrm{p}<0,05)$. Gambar 3 menunjukkan bahwa kadar IL-17 pada kelompok DMT1 $(146,2 \pm 45,5) \mathrm{pg} / \mathrm{mL})$ secara signifikan lebih tinggi dibandingkan kelompok kontrol $(11,2 \pm 5,4) \mathrm{pg} /$ $\mathrm{mL}$ (independent $t$-test, $\mathrm{p}<0,05$ ) tertera pada Gambar 2.

Tabel 1. Karakteristik subjek penelitian

\begin{tabular}{lcc}
\hline Karakteristik & $\begin{array}{c}\text { DM Tipe } 1 \\
(\mathrm{n}=20)\end{array}$ & $\begin{array}{c}\text { Kontrol } \\
(\mathrm{n}=20)\end{array}$ \\
\hline Rerata usia (tahun) & $12,25 \pm 3,7$ & $11 \pm 2,51$ \\
Distribusi usia (tahun) & & \\
5 & 0 & 0 \\
$5-10$ & $6 / 20$ & $8 / 20$ \\
$11-15$ & $9 / 20$ & $12 / 20$ \\
$\quad>15$ & $5 / 20$ & 0 \\
Jenis kelamin & & \\
$\quad$ Laki-laki & 6 & 9 \\
$\quad$ Perempuan & 14 & 11 \\
Rerata lama DM (tahun) & $4,4 \pm 2,4$ & 0 \\
Status gizi & & \\
$\quad$ Baik & 15 & 13 \\
$\quad$ Kurang & 5 & 8 \\
Rerata dosis insulin (IU/kg/hari) & $1,3 \pm 0,3$ & 0 \\
Frekuensi pemantauan gula darah mandiri (x/hari) & & \\
$\quad$ 1-2 & 20 & 0 \\
$\quad>2$ & 0 & \\
\hline
\end{tabular}


Tabel 2. Karakteristik berdasarkan gambaran hasil laboratorium

\begin{tabular}{|c|c|c|c|c|c|c|c|}
\hline \multirow{2}{*}{\multicolumn{2}{|c|}{ Hasil laboratorium }} & \multicolumn{3}{|c|}{ DM tipe $1(n=20)$} & \multicolumn{3}{|c|}{ Kontrol (n=20) } \\
\hline & & $\mathrm{n}$ & Rerata $\pm S D$ & Rentang & $\mathrm{n}$ & Rerata \pm SD & Rentang \\
\hline \multicolumn{2}{|c|}{ Hemoglobin (g/dL) } & & $12,2 \pm 0,6$ & $11,5-13,5$ & & $12,4 \pm 0,6$ & $12-14$ \\
\hline \multicolumn{2}{|c|}{ Leukosit (g/dL) } & & $8531 \pm 1147,86$ & $7960-9870$ & & $7785 \pm 1140,79$ & $5100-9420$ \\
\hline \multicolumn{2}{|c|}{ Trombosit (g/dL) } & & $101592,5 \pm 165684,8$ & $301000-392000$ & & $327,8 \pm 45,8$ & $275000-394000$ \\
\hline \multicolumn{2}{|c|}{ Ureum (mg/dL) } & & $22,40 \pm 4,3$ & $18-29,1$ & & $23,08 \pm 2,6$ & $20,1-30,2$ \\
\hline \multicolumn{2}{|c|}{ Creatinin $(\mathrm{mg} / \mathrm{dL})$} & & $0,6 \pm 0,1$ & $0,4-0,9$ & & $0,5 \pm 0,2$ & $0,3-0,8$ \\
\hline \multicolumn{2}{|c|}{ SGOT (U/L) } & & $30,1 \pm 2,4$ & $23-39$ & & $28,9 \pm 3,9$ & $24-35$ \\
\hline \multicolumn{2}{|c|}{ SGPT (U/L) } & & $31,1 \pm 1,8$ & $27-36$ & & $30,7 \pm 2,7$ & $27-39$ \\
\hline \multicolumn{2}{|c|}{ HbA1c (\%) } & & $9,8 \pm 1,7$ & $7-14,5$ & & $5,0 \pm 0,2$ & $4,7-5,4$ \\
\hline \multicolumn{2}{|l|}{$<6,5$} & $0 / 20$ & & & & & \\
\hline \multicolumn{2}{|l|}{$6,5-7,6$} & $3 / 20$ & & & & & \\
\hline \multicolumn{2}{|l|}{$7,6-9$} & $3 / 20$ & & & & & \\
\hline \multicolumn{2}{|l|}{$>9$} & $14 / 20$ & & & & & \\
\hline Vitamin D & Defisiensi & $12 / 20$ & $16,8 \pm 3,1$ & $11,9-19,8$ & $0 / 20$ & - & \\
\hline \multirow[t]{2}{*}{$(\mathrm{ng} / \mathrm{mL})$} & Insufisiensi & $6 / 20$ & $24,4 \pm 3,4$ & $20,3-29,4$ & $0 / 20$ & - & \\
\hline & Normal & $2 / 20$ & $31,3 \pm 0,7$ & $30,8-31,8$ & $20 / 20$ & $33,9 \pm 3,6$ & $30,4-38,3$ \\
\hline \multicolumn{2}{|c|}{ IL-17 (pg/mL) } & & $146,2 \pm 45,50$ & & & $11,2 \pm 75,4$ & \\
\hline
\end{tabular}

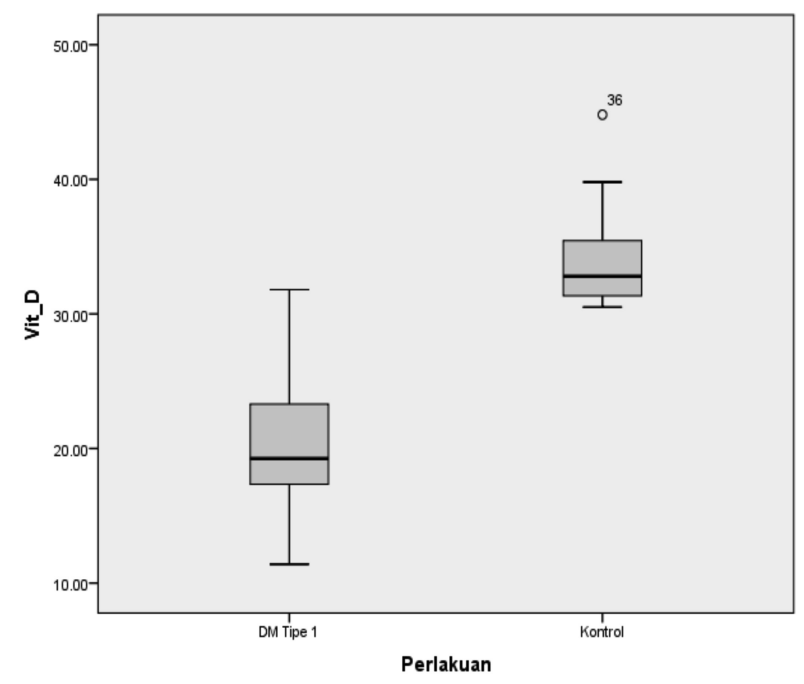

Gambar 1. Histogram perbandingan kadar vitamin D pada kelompok DMT1 dan kontrol

Uji korelasi pada kelompok DMT1 menunjukkan bahwa peningkatan kadar vitamin $\mathrm{D}$ berhubungan dengan peningkatan kadar IL-17 $\left(\mathrm{p}<0,05, \mathrm{R}^{2}=\right.$ 0,566), sedangkan peningkatan IL-17 berhubungan dengan penurunan kadar $\mathrm{HbA} 1 \mathrm{c}\left(\mathrm{p}<0,05, \mathrm{R}^{2}=\right.$

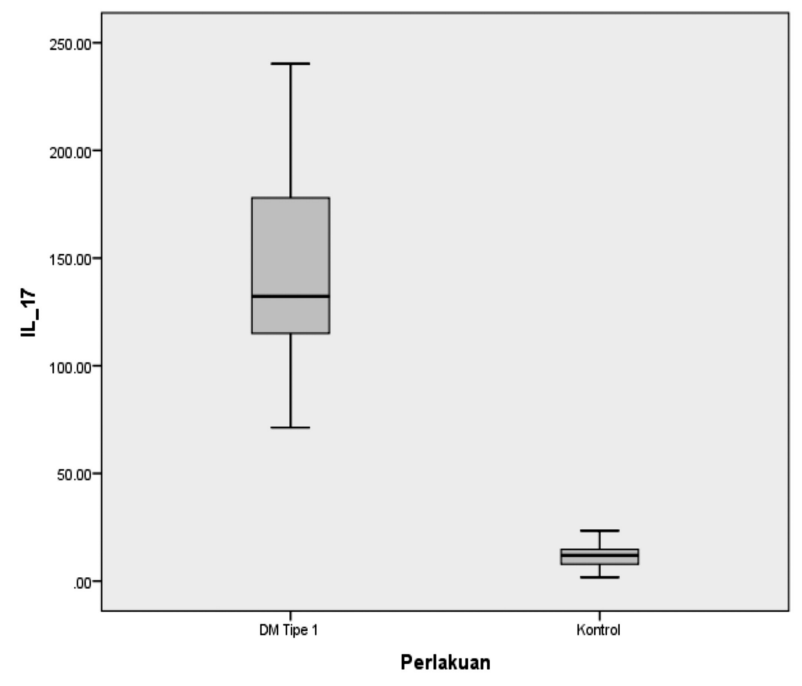

Gambar 2. Histogram perbandingan kadar HbA1c pada kelompok DMT1 dan kontrol

0,489). Gambar 4 menunjukkan bahwa semakin tinggi kadar vitamin D semakin tinggi kadar IL17. Sementara itu, Gambar 5 menunjukkan bahwa semakin tinggi kadar IL-17, kadar HbA1c pada anak DMT1 semakin rendah. Semakin tinggi kadar 


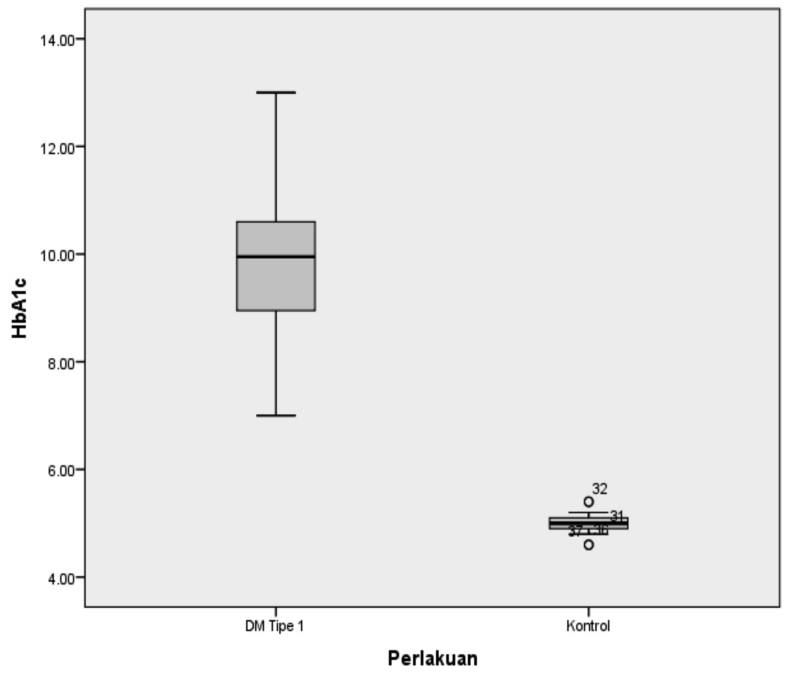

Gambar 3. Histogram perbandingan kadar IL-17 pada kelompok DMT1 dan kontrol

\section{Hubungan antara kadar 25(OH)D dengan IL-17 pada anak DMT1}

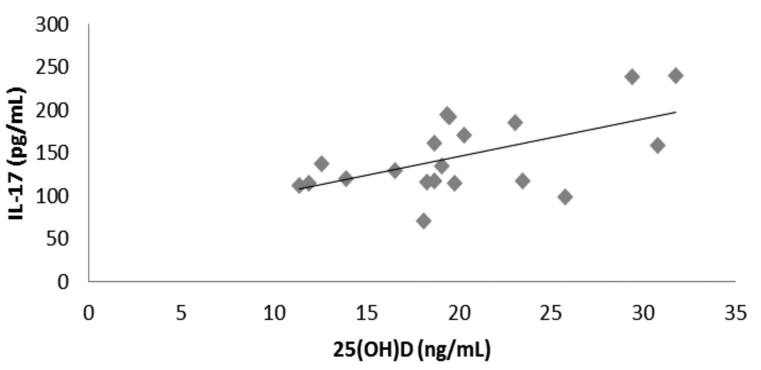

Gambar 4. Hubungan antara kadar 25(OH)D dengan IL-17 pada anak dengan DMT1

Hubungan antara kadar IL-17 dengan HbA1c pada anak DMT1

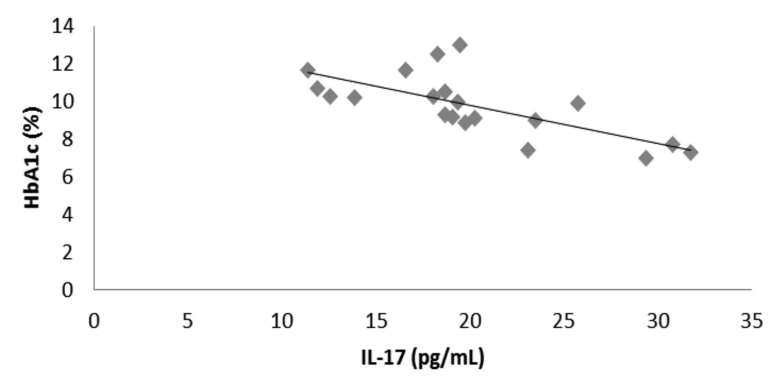

Gambar 5. Hubungan antara kadar IL-17 dengan HbA1c pada anak dengan DMT1

\section{Hubungan antara kadar 25(OH)D dengan HbA1c pada anak DMT1}

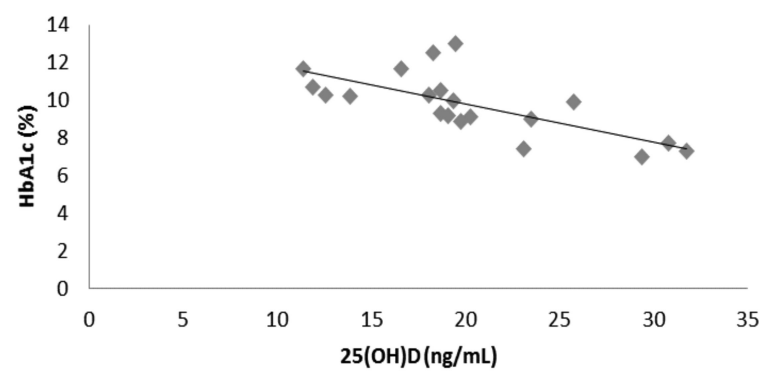

Gambar 6. Hubungan antara kadar vitamin D dengan HbA1c pada anak dengan DMT1

vitamin $\mathrm{D}$, kadar HbA1c pada anak DMT1 juga semakin rendah (Gambar 6). Namun demikian, analisis jalur menunjukkan bahwa vitamin D berpengaruh tidak signifikan terhadap $\mathrm{HbA} 1 \mathrm{c}$ melalui IL-17 $\left(p>0,05, R^{2}=-0,267\right)$.

\section{Pembahasan}

Penelitian ini melibatkan 40 subjek, terbagi 2 kelompok, yaitu kelompok DMT1 dan kontrol. Vitamin D diakui sebagai hormon, disintesis dalam tubuh manusia dan beraktivitas pada organ lain melalui reseptor vitamin D (VDR). Terdapat 3 bentuk vitamin D, yaitu secosterols, ergocalciferol (VD2) dan cholecalciferol (VD3). Ergocalciferol (VD2) diproduksi melalui iradiasisterol (ergosterol), sedangkan VD3 terutama diproduksi di kulit dari 7-dehidro kolesterol melalui sintesis fotokimia menggunakan radiasi sinar UV. ${ }^{14}$ Peneliti yang sama menyimpulkan bahwa vitamin D2 (VD2) atau 25(OH)D yang beredar merupakan indikator status vitamin D. Pada penelitian kami, kadar 25(OH)D digunakan untuk mengetahui status vitamin D, baik pada anak DMT1 maupun kontrol.

Pada kelompok DMT1, semua subjek menggunakan $\mathrm{GAD}_{65}$ sebagai penanda DMT1 dan hasilnya positif. Martin $\mathrm{dkk}^{15}$ melaporkkan bahwa paparan $\mathrm{GAD}_{65}$ dan $\mathrm{GAD}_{67}$ menyebabkan proliferasi sel T meningkat lebih dini, yaitu pada usia 4 minggu 
pertama tikus NOD, bertepatan dengan timbulnya insulitis. Selain itu, Vafiadis $\mathrm{dkk}^{16}$ melaporkan keberadaan gen INS yang memberikan kontribusi $10 \%$ terhadap kerentanan genetik pada terjadinya diabetes melitus autoimun melalui mekanisme penekanan insulin auto antibody (IAA). Gough $\mathrm{dkk}^{17}$ dan Mathieu $\mathrm{dkk}^{18}$ melaporkan peran gen yang mengatur ekspresi CTLA-4 yang merupakan reseptor sel T pada proses autoimun DMT1. Ekspresi reseptor ini akan menghambat proses inflamasi melalui penekanan produksi IL-2 dan polimorfismenya menyebabkan peningkatan risiko penyakit autoimun, termasuk DMT1.

Karakteristik dasar subjek menunjukkan bahwa pada kelompok DMT1 menunjukkan kadar vitamin D lebih rendah dibandingkan kelompok kontrol. Pada kelompok DMT1, berdasarkan kadar 25(OH)D menurut Balasubramanian $\mathrm{dkk},{ }^{19}$ dilaporkan defisiensi $12 / 20(<20 \mathrm{ng} / \mathrm{mL})$, insufisiensi 6/20 (21-29) $\mathrm{ng} /$ $\mathrm{mL}$, dan $2 / 20$ normal $(>30 \mathrm{ng} / \mathrm{mL}$ ). Berbeda dengan kelompok DMT1, pada kelompok kontrol rerata kadar $25(\mathrm{OH}) \mathrm{D}$ tergolong normal. Uji beda menunjukkan lebih lanjut bahwa kadar $25(\mathrm{OH}) \mathrm{D}$ pada kelompok DMT1 lebih tinggi dibandingkan kelompok kontrol.

Glycated hemoglobin (HbA1c) merupakan komponen utama hemoglobin adult (HbA) $80 \%(20,2)$ dan kadarnya menggambarkan riwayat pengendalian glukosa darah dalam waktu 90-120 hari terakhir sesuai dengan rerata umur eritrosit. ${ }^{21}$ Selain menggambarkan riwayat pengendalian glukosa darah, HbA1c juga dijadikan indikator prognosis pada pasien DM. ${ }^{22} \mathrm{Kami}$ mendapatkan rerata kadar HbA1c pada kelompok DMT1 lebih tinggi signfikan dibandingkan kelompok kontrol.

Hasil penelitian kami menunjukkan bahwa kadar IL-17 pada kelompok DMT1 lebih tinggi bermakna dibandingkan kelompok kontrol. Temuan tersebut sesuai dengan laporan penelitian sebelumnya bahwa ekspresi sel Th17 dan sekresinya (IL-23) meningkat pada pankreas tikus non obese diabetes (NOD) dan berperan pada eksaserbasi diabetes serta ekspansi jaringan lain (kelenjar limfe pankreas dan sirkulasi) fenotipik dan fungsional. ${ }^{23-25}$ Sel Th17 berasal dari sel T-naif yang terinduksi oleh beberapa senyawa biokimia dan merupakan subset dari sel T helper CD4+ yang ditandai dengan produksi sitokin penandanya, IL-17 $(26,27)$. Sel Th17 yang teraktivasi akan mensekresikan IL-17A, IL-17F, IL-21, IL-22, dan TNF- $\alpha$ yang kemudian menimbulkan proses inflamasi jaringan dengan induksi mediator proinflamasi lainnya dan perekrutan leukosit, terutama neutrofil ke situs inflamasi. ${ }^{28}$ Proses autoimun pada DMT1 telah dilaporkan berkaitan dengan proliferasi dan aktivasi sel T helper 17 (Th17). ${ }^{6}$

Pada penelitian kami menunjukkan korelasi positif antara kadar 25(OH)D dengan IL-17. Hasil tersebut berbeda dengan beberapa penelitian sebelumnya. Penelitian sebelumnya melaporkan bahwa vitamin D3 (1,25(OH)2D3) mempunyai kemampuan menghambat produksi (downregulation) IL-17A dan beberapa sitokin lain. ${ }^{29}$ Pada kasus reumatoid artritis, sklerosis multipel, dan kolitis tahap awal. ${ }^{30}$ Mekanisme hambatan produksi IL17A ada pada tingkat nuclear factor for activated $T$ cells (NFAT). ${ }^{31}$ Penurunan faktor transkripsi ROR $\gamma \mathrm{t}$ menyebabkan penekanan mRNA yang berperan pada proses diferensiasi sel Th $17,{ }^{32}$ dan upregulation (regulasi naik) pada ekspresi FoxP3 dengan adanya peningkatan TGF- $\beta 1 .{ }^{13}$ Penelitian mengenai peran vitamin D dengan IL-17 dan kontrol glikemik juga telah banyak dilakukan. Suplementasi 1,25(OH)2D3 secara bermakna mengurangi kejadian diabetes sampai $80 \%$ pada tikus NOD tipe 1 dan menurunkan $33 \%$ risiko berkembang menjadi DMT1 pada anak yang menerima suplementasi vitamin D 2000 IU dibandingkan kontrol. ${ }^{17}$ Meta analisis oleh Zipitis dan Akobeng ${ }^{33}$ melaporkan bahwa suplementasi vitamin D pada awal kehidupan mampu memberikan perlindungan terhadap terjadinya DMT1 karena efek proteksinya terhadap sitokin inflamasi pada sel $\beta$ pankreas. Studi prospektif oleh Aljabri dkk ${ }^{34}$ juga melaporkan bahwa pasien yang mencapai tingkat sirkulasi kadar 25(OH)D lebih tinggi memiliki kadar HbAlc yang rendah.

Kontradiksi tersebut kemungkinan diakibatkan oleh parameter pengukuran yang berbeda. Pada penelitian kami yang diukur adalah $25(\mathrm{OH}) \mathrm{D}$ bukan $1,25(\mathrm{OH}) 2 \mathrm{D} 3$. Selain itu, desain penelitian kami cross-sectional dan analisis hanya dilakukan pada kelompok DMT1. Di samping itu pula, untuk menilai hubungan kadar $25(\mathrm{OH}) \mathrm{D}$ dengan keterlibatan sel Th17 pada kasus DMT1 diperlukan penghitungan secara kuantitatif.

Hasil penelitian juga menunjukkan bahwa kadar IL-17 berkorelasi negatif dengan kadar HbA1c. Hasil tersebut tidak sesuai dengan penelitian sebelumnya yang melaporkan korelasi postif antara ekspresi 
dan aktivitas Th17 dengan kontrol glikemik. Penelitian sebelumnya melaporkan bahwa terdapat up-regulation sel Th 17 dan defek fungsional sel Treg pada kelenjar limfe pankreas pada pasien DMT1 $1^{29,35}$ dan peningkatan aktivitas sel ini menyebabkan eksaserbasi klinis DMT 1, lesi insulitik, dan peningkatan ekspresi IL-17 pankreas. ${ }^{11,12} \mathrm{HbA1c}$ merupakan penunjuk dari rerata kadar glukosa plasma dan digunakan sebagai marker kontrol glikemik. ${ }^{36}$ Kontrol glikemik yang direpresentasikan HbA1c berkorelasi positif dengan marker inflamasi sistemik (misalnya C-Reactive Protein (CRP), IL-6, IL-8, dan IL-18) ${ }^{37}$ dan berkorelasi negatif dengan sitokin anti-inflamasi (IL-10). ${ }^{38}$ Kadar rerata HbA1c pada kelompok DMT1 dengan terapi insulin dosis $1,285 \pm 0,262 \mathrm{U} / \mathrm{hari}$ menunjukkan kontrol glikemik yang masih buruk.

Hasil uji analisis jalur menunjukkan kadar 25(OH) D berpengaruh tidak bermakna terhadap kadar HbA1c melalui IL-17. DMT1 dan kontrol glikemik dipengaruhi oleh berbagai macam factor, seperti imunologis (sitokin Th1 [IL-2, IFN- $\gamma$, TNF- $\alpha$ ] dan Th2 [IL-4, IL-5, IL-10]), ${ }^{39}$ genetik yang berkaitan dengan kembar monozigot ${ }^{40}$ dan HLA tipe DR4-DQ8 atau DR3-DQ2. ${ }^{16,41}$

Kelemahan penelitian kami adalah desain dan variabel yang digunakan. Desain penelitian cross sectional menyebabkan pengukuran kadar $25(\mathrm{OH})$ D, IL-17, dan HbA1c pada satu kurun waktu dan belum mampu menggambarkan interaksi ketiga parameter tersebut (sebab-akibat) mengingat DMT1 merupakan penyakit autoimun dan bersifat kronik. Variabel vitamin D yang digunakan bukan merupakan bentuk vitamin D aktif yang berpengaruh secara langsung terhadap aktivitas sel Th17 dan harus melalui metabolisme di ginjal. Sebagai saran, pada penelitian selanjutnya perlu dikembangkan pengukuran jumlah populasi sel Th17 dan sitokin lain yang berperan pada DMT1, misalnya IL-23 dan IL-22.

\section{Kesimpulan}

Kadar vitamin D lebih rendah pada kelompok DMT1, tetapi kadar HbA1c dan IL-17 lebih tinggi pada kelompok DMT1. Pada kelompok DMT1, vitamin $\mathrm{D}$ berhubungan dengan HbA1c melalui IL-17, tetapi tidak signifikan.

\section{Daftar pustaka}

1. Craig ME, Hattersley A, Donaghue K. Definition, epidemiology and classification of diabetes in children and adolescents. Pediatr Diabetes 2009;7:3-12.

2. Batubara JRL. Audit of childhood diabetes control in Indonesia. Paediatr Indones 2002; 42:280-6.

3. Cahyono HA, Wulandari D, Ratnasari V. Short term complication of type 1 diabetes mellitus. Pediatrica Indones 2013;53:92.

4. Korn T, Bettelli E, Oukka M, Kuchroo VK. IL-17 and IL-17 cells. Annu Rev Immunol 2009;27: 485-517.

5. McGeachy DJ. IL-17 cell differentiation: the long and winding road. Immunity 2008;28:445-53.

6. Dong C. IL-17 cells in development: an updated view of their molecular identity and genetic programming. Nat Rev Immunol 2008;8:337-48.

7. Bettelli E, Oukka M, Kuchroo VK. IL-17 cells in the circle of immunity and autoimmunity. Nat Immunol 2007;8:345-50.

8. Hafler DA, Kelinewietfeld M, Manzel A. Sodium chloride drives autoimmune disease by the induction of pathogenic IL-17 cells. Nature; 2013.

9. Cantorna MT, Zhu Y, Froicu M, Wittke A. Vitamin D status, 1,25-dihydroxyvitamin D3, and the immune system in department of nutritional sciences, Pennsylvania State University. J Clin Nutr 2004;80:1717S-20S.

10. Szodoray P, Nakken B, Gaal J, Jonsson R, Szegedi A, Zold E. The complex role of vitamin $\mathrm{D}$ in autoimmune diseases. J Immunol 2008;68:261-9.

11. Emmamuelle JA, Davis J, Merani S, Toso C, Elliot JF, Tiesson A, Shapiro AM. Inhibition of Th 17 cells regulates autoimmune diabetes in NOD mice. Diabetes 2008;58:1302-11.

12. Martin-Orozco N, Chung YS, Chang SH, Wang YH, Dong C. Th 17 cells promote pancreatic inflammations but only induce diabetes efficiently in lymphopenic hosts after conversion to Th 1 cells. Eur J Immunol 2009;39:216-24.

13. Shao S, He F, Yang Y, Yuan G, Zhang M, Yu X. Th17 cells in type 1 diabetes. Cell Immunol 2012;280:16-21.

14. DeLuca HF. Overview of general physiologic features and functions of vitamin D. Am J Clin Nutr 2004;80:1689S-96S.

15. Martin S, Wolf-Eichbaum D, Duinkerken G. Developmental of type 1 diabetes despite severe hereditary b-lymphocyte deficiency. N Engl J Med 2000;345:103640 . 
16. Vafiadis P, Benne ST, Todd JA. Insulin expression in human thymus is modulated by INS VNTR alleles at the IDDM2 locus. Nat Gen 2007;15:289-92.

17. Gough SC, Walker LS, Sansom DM. CTLA4 gene polymorphism and autoimmunity. Immunol 2005;204:10215.

18. Mathieu C, Gysemans C, Giuletti A, Bouillon R. Vitamin D and diabetes. Diabetologia 2005;48:124757.

19. Balasubramanian S, Dhalanalaksmi K, Amperayani S, Bjork E, Kampe O, Andersson A, dkk. Expression of the $64 \mathrm{kDa}$ glutamic acid decarboxylase rat islet cell autoantigen is influenced by the rate of insulin secretion. Diabetologia 2013;35:490-93.

20. Sacks DB. Measurement of hemoglobin A1c: a new twist on the path of harmony. Diabetes Care 2012;35:2674-8.

21. Derr R, Garrett E, Stacy GA, Saudek CD. Is HbA1c affected by glycemic instability? Diabetes Care. 2003; 26: 2728-33.

22. Goldstein DE, Little RR, Lorenz RA, Malone JI, Nathan $\mathrm{D}$, Peterson CM. Tests of glycemia in diabetes. Diabetes Care 2004;27:1761-73.

23. Vukkadapu SS, Belli JM, Ishii K. Dynamic Interaction between $\mathrm{T}$ cell mediated beta-cell damage and beta-cell repaired in the run up to autoimmune diabetes of the NOD mice. Physiol Genomic 2005;21: 201-11.

24. Honkanen J, Nieminen JK, Gao R. IL-17 Immunity in human type 1 diabetes. J Immunol 2010;185:1959-67.

25. Mensah-Brown EP, Shahin A, Al-Shamisi M. IL-23 leads to diabetes induction after subdiabetogenic treatment with multiple low doses of streptozotocin. Eur J Immunol 2006;36:216-23.

26. Harrington LE, Hatton RD, Mangan PR, Turner H, Murphy TL, Murphy KM. Interleukin 17-producing CD4+ effector $\mathrm{T}$ cells develop via a lineage distinct from the $T$ helper Type 1 and 2 lineages. Nat Immunol 2005;6:1123-32.

27. Romagnani S. Human IL-17 cells. Arthritis Res Ther 2008;10:206.

28. Simone Kennedy Bedoya, Brandon Lam, Kenneth Lau, Joseph Larkin III. IL-17 cells in immunity and autoimmunity. Clin and Develop Immunol; 2013.

29. Khoo AL, Chai LY, Koenen HJ, Kullberg BJ, Joosten I, van der Ven A, dkk. 1,25-dihydroxyvitamin $D_{3}$ modulates cytokine production induced by Candida albicans: impact of seasonal variation of immune responses. J Infect Dis 2011;203:122-30.

30. Chang JH, Cha HR, Lee DS, Seo KY, Kweon MN. 1,25-dihydroxyvitamin $\mathrm{D}_{3}$ inhibits the differentiation and migration of $\mathrm{T}(\mathrm{h}) 17$ cells to protect against experimental autoimmune encephalomyelitis. Plos ONE 2010;5:12925.

31. Gomez-Rodriguez J, Nisebita S, Handon R, Davidson TS, Anderson SM, Kirby MR, dkk. Differential expression of interleukin-17A and $-17 \mathrm{~F}$ is coupled to $\mathrm{T}$ cell receptor signaling via inducible $\mathrm{T}$ cell kinase. Immunity 2009;31:587-97.

32. Palmer HG, Gonzales-Sancho JM, Espada J, Berciano MT, Puig I, Baulida J, dkk. Vitamin D(3) promotes the differentiation of colon carcinoma cells by the induction of E-cadherin and the inhibition of beta-catenin signaling. J Cell Biol 2001;154:369-87.

33. Zipitis CS, Akobeng AK. Vitamin D supplementation in early childhood and risk of type 1 diabetes mellitus. A systematic review and meta analysis Arch Dis Child 2008;93:512-7.

34. Aljabri KS, Bokhari SA, Khan MJ. Glycemic changes after vitamin $\mathrm{D}$ supplementation in patients with type 1 diabetes mellitus and vitamin d deficiency. Ann Saudi Med 2010;30:454-8.

35. Ferraro A, Socci C, Stabilini A, Valle A, Monti P, Piemonti L. Expansion of Th17 cells and functional defects in $\mathrm{T}$ regulatory cells are key features of the pancreatic lymph nodes in patients with type 1 diabetes. Diabetes 2011;60:2903-13.

36. Rohlfing CL, Wiedmeyer HM, Little RR, England JD, Tennill A, Goldstein DE. Defining the relationship between plasma glucose and HbA1c: analysis of glucose profiles and $\mathrm{HbA} 1 \mathrm{c}$ in the diabetes control and complications trial. Diabetes Care 2002;25:2758.

37. Miulescu RD, Panus A, Suzana D, Alexe O, Seraficeanu C, Neamtu MC. Prevalence of hammer toes in diabetic patients with distal symmetric polyneuropathy. Rom J Funct Clin Macro- Microscopia 2011;13:227.

38. Sawah SI. A Cross-sectional study of vitamin D, glycemic control, and inflammatory cytokines in children and adolescents with type 1 diabetes mellitus, disertasi. Pennsylvania: University of Pennsylvania, 2011.

39. Rabinovitch A. An update on cytokines in the pathogenesis of insulin-dependent diabetes mellitus. Diabetes Metab Rev 1998;12:129-51.

40. Bruno G, Pagano G, Faggiano F, De Salvia A, Merletti F. Effect of Sardinian Heritage on risk and age at onset of type 1 diabetes: a demographic casecontrol study of Sardinian migrants. Int J Epidemiol 
2000;29:532-5.

41. Noble JA, Valdes AM, Cook M, Klitz W, Thomson G, Erlich HA. The role of HLA class II genes in insulin- dependent diabetes mellitus: molecular analysis of 180 Caucasian, Multiplex Families. Am J Hum Genet 1996;59:1134-48. 